Original Contribution

\title{
EFFECT OF FEEDING GRADED LEVELS OF COWPEA (VIGINA UNGUICULATA) TESTA MEAL ON GROWTH AND ECONOMIC PERFORMANCE OF GROWING RABBITS
}

\author{
J. U. Igwebuike, G. Mohammed, I. D. Kwar, O. L. Abiola, U. M. Kolo* \\ Department of Animal Science, University of Maiduguri, Maiduguri, Nigeria
}

\begin{abstract}
An 8-week feeding trial was conducted to assess the growth and economic performance of growing rabbits fed graded levels of cowpea testa meal (CTM). Wheat offal was replaced with cowpea testa meal at $0,25,50,75$ and $100 \%$ levels in diets 1, 2, 3, 4 and 5, respectively. Twenty- five crossbred rabbits (Dutch X New Zealand White) between $5-7$ weeks of age were randomly allocated to the 5 treatments in groups of 5 rabbits and allowed unlimited access to the feed and drinking water throughout the experimental period. The daily weight gain and feed conversion ratio were not significantly $(\mathrm{P}>0.05)$ different among the treatments while the final body weight and daily feed intake were affected by the inclusion of cowpea testa meal (CTM) in the diets. Rabbits fed T2 (25\% cowpea testa meal) diet recorded the highest final body weight while those fed T5 (100\% cowpea testa meal) diet recorded the least; other treatments were similar to the control (0\% CTM). Rabbits fed T2 (25\% cowpea testa meal) diet consumed more feed compared to rabbits fed other diets. The cost per $\mathrm{kg}$ feed decreased as the level of CTM increased in the diets. The best cost per kilogram of weight gain was obtained by rabbits fed T4 $(75 \%$ cowpea testa meal) diet while the poorest was recorded by rabbits fed T2 (10\% cowpea testa meal) diet. Therefore, $100 \%$ of the wheat offal in the diets of growing rabbits could be replaced with cowpea testa meal without adverse effects on growth and economic performance.
\end{abstract}

Key words: Cowpea testa meal, growing rabbit, growth and economic performance

\section{INTRODUCTION}

There is deficit of animal protein in diets of people in the third world countries like Nigeria, where it is estimated that on average only $10 \mathrm{~g}$ of animal protein is consumed per day per head against $35 \mathrm{~g}$ recommended by (12). Mini livestock production has been identified as the possible means to bridge the protein shortage of the undernourished average African people (3). The advocacy for expanding mini-livestock production particularly rabbit, is due to short generation interval, high prolificacy, good mothering ability, ability to utilize forage and other unconventional feed sources (4). Nutritionally, rabbit meat is high in protein but low in fat and cholesterol, and highly digestible with dressing percentage of 82 to $85 \%$ (5).

(6) stated that conventional feeds account for about $70 \%$ of total cost of rabbit production making them expensive to most farmers.

\footnotetext{
*Correspondence to: U. M. Kolo, Department of Animal Science, University of Maiduguri,

Maiduguri, Nigeria, e-mail:uskolo220@gmail.com, Phone number: +2348038329041
}

Recent difficulties with animal production inputs in Nigeria and the high cost of feed ingredients in particular have brought about the need to look for cheaper alternatives to the conventional feed resources. These products could be cheaply available for compounding livestock feeds as it will reduce or remove the competition between man and livestock (7). Cowpea (Vigina unguiculata) otherwise known as "beans" is very popular among households in Africa and is a widely grown leguminous crop in Nigeria. The testa covering the cotyledons of the bean is usually removed during the processing and this by-product can be fed to ruminants (8). Currently, its use in rabbit feeding is limited, hence the need for further research. This study was therefore, conducted to evaluate the effect of feeding different levels of cowpea testa meal on growth and economic performance of growing rabbits.

\section{MATERIALS AND METHODS Experimental Animals and Management}

The study was conducted at the Livestock Teaching and Research Farm, University of Maiduguri, Maiduguri, Borno State, Nigeria. 
Twenty-five crossbred rabbits (Dutch $\mathrm{x}$ New Zealand white) between 5 and 7 weeks of age were used for the $8-$ week feeding trial. The rabbits were individually weighed, equalized for weight and randomly assigned to the five (5) treatments in groups of five (5). Each rabbit was caged individually. The rabbits were provided with the experimental diets and clean drinking water ad libitum. Data collection commenced after an initial adjustment period of seven days.

\section{Experimental Diets}

The experimental diets are shown in Table 1. Maize, wheat offal, groundnut haulm, groundnut cake, fish meal, cowpea testa meal, bone meal, common salt and premix were used in compounding the experimental diets. Cowpea testa meal (CTM) replaced wheat offal at levels of $0,25,50,75$ and $100 \%$ in diets 1 (control), 2, 3, 4 and 5, respectively.

Table 1. Ingredient Composition of the experimental diets

Levels of wheat offal replaced with cowpea testa meal

\begin{tabular}{llllll} 
Ingredients $(\%)$ & $\mathrm{T} 1(0 \%)$ & $\mathrm{T} 2(25 \%)$ & $\mathrm{T} 3(50 \%)$ & $\mathrm{T} 4(75 \%)$ & $\mathrm{T} 5(100 \%)$ \\
\hline Maize & 40.98 & 40.98 & 40.98 & 40.98 & 40.98 \\
Wheat offal & 17.00 & 12.75 & 8.50 & 4.25 & 0.00 \\
Cowpea testa meal & 0.00 & 4.25 & 8.50 & 12.75 & 17.00 \\
Groundnut cake & 23.37 & 23.37 & 23.37 & 23.37 & 23.37 \\
Fish meal & 3.00 & 3.00 & 3.00 & 3.00 & 3.00 \\
Groundnut haulms & 13.00 & 13.00 & 13.00 & 13.00 & 13.00 \\
Bone meal & 2.00 & 2.00 & 2.00 & 2.00 & 2.00 \\
Common Salt $(\mathrm{NaCl})$ & 0.50 & 0.50 & 0.50 & 0.50 & 0.50 \\
Premix* & 0.15 & 0.15 & 0.15 & 0.15 & 0.15 \\
Total & $\mathbf{1 0 0 . 0 0}$ & $\mathbf{1 0 0 . 0 0}$ & $\mathbf{1 0 0 . 0 0}$ & $\mathbf{1 0 0 . 0 0}$ & $\mathbf{1 0 0 . 0 0}$ \\
\hline
\end{tabular}

*Premix (grow fast) manufactured by Animal Care Service Consult (Nig) Ltd. Lagos, Supplied the following per $\mathrm{kg}$ of premix: Vitamin A, 5000,00 IU; Vitamin $\mathrm{D}_{3} 800,000 \mathrm{IU}$; Vitamin E, 12,000 mg; Vitamin K, 1,5000 mg; Vitamin $B_{1}, 1,000 \mathrm{mg}$; Vitamin $B_{2}, 2,000 \mathrm{mg}$, Vitamin $B_{6}, 1,500 \mathrm{mg}$; niacin, $12,000 \mathrm{mg}$; pantothenic acid, 20.00 $\mathrm{mg}$; biotin, $10.00 \mathrm{mg}$; Vitamin $\mathrm{B}_{12}, 300.00 \mathrm{mg}$; folic acid, $150,000 \mathrm{mg}$; choline, 60,000 mg; manganese, 10,000 mg; iron; $15,000 \mathrm{mg}$, zinc $800.00 \mathrm{mg}$; copper $400.00 \mathrm{mg}$; iodine $80.00 \mathrm{mg}$; cobalt $40 \mathrm{mg}$; selenium 8,00 mg.

\section{Data collection}

The daily feed intake was obtained by subtracting the left-over from total amount of feed supplied. Each rabbit was weighed at the inception of the experiment and weekly thereafter to obtain the weekly and daily body weight gain throughout the experimental period. The feed conversion ratio was calculated as the dry matter feed intake per unit weight gain. The proximate composition of the diets and test material (cowpea testa meal) were determined according to (9).

\section{Economic analysis}

The economic implication of including cowpea testa meal in the diets of growing rabbits was assessed by calculating the:

(i) Total feed intake per rabbit;

(ii) Total weight gain;

(iii) Cost per kilogramme of each diet;

(iv) Cost per kilogramme of weight gain by the rabbit.

\section{Statistical Analysis}

Data collected were subjected to analysis of variance and where significant differences were observed, means were compared by Duncan's multiple range test (10) as outlined by (11). Computer package statistix version 9.0 was used for the analysis.

\section{RESULTS AND DISCUSSION \\ Proximate Composition of the Experimental Diets and Cowpea Testa Meal}

The proximate composition of the experimental diets and the cowpea testa meal are shown in Table 2. The crude protein $(22.06 \%)$ of the cowpea testa meal is lower than the value reported by (8) but higher than the value (18.0\%) reported by (13). However, the crude fibre value $(10.07 \%)$ is higher than $7.85 \%$ reported by (8) and lower than $13.6 \%$ reported by (13) The difference in the levels of crude protein and crude fibre may be due to different methods of processing cowpea testa meal by the producers. Values for ether extract and ash content were similar to the results of other authors $(13 ; 8)$ who analyzed cowpea testa. The crude protein levels of the experimental diets (16.03 to 18.57\%) are higher than the value reported by (14) that incorporated abattoir waste in the diets of rabbits. However, the values reported here are 
IGWEBUIKE J. U., et al.

close to the recommended levels of $15 \%$ and $13 \%$ for growth and maintenance, respectively reported by (15). The crude fibre of the experimental diets ranged from 8.0 to $14.0 \%$ which is higher than 6.25 to $12.50 \%$ reported by (17), but adequate for rabbit diet as reported by (18). This is also in line with the observation of (19) who found that crude fibre levels of 10 to $17 \%$ could support weight gain and normal gut function in rabbits. The ether extract $(3-4 \%)$ of the experimental diets were similar and adequate for growing rabbit. (20) reported that a minimum level of $3 \%$ fat is adequate to meet the requirement of the rabbit. The lowest value of ash content was reported in T4 (75\% CTM) diet but higher values were obtained in T3 (50\% CTM) and T5 (100\% CTM), respectively. The $\mathrm{T} 1 \quad(0 \%$ CTM $)$ recorded the highest value of nitrogen-free extract (NFE) while the lower values were obtained in T3 (50\% CTM) and T5 (100\% CTM), respectively. The metabolisable energy of the experimental diets was similar to the value $(2800 \mathrm{Kcal} / \mathrm{kg})$ reported by (21) for growing rabbit.

Table 2. Proximate composition (\%) of the experimental diets and cowpea testa meal (CTM)

\begin{tabular}{lllllll}
\hline & \multicolumn{5}{c}{ Levels of wheat offal replaced with cowpea testa meal } \\
Parameters & $\mathrm{T} 1(0 \%)$ & $\mathrm{T} 2(25 \%)$ & $\mathrm{T} 3(50 \%)$ & $\mathrm{T} 4(75 \%)$ & $\mathrm{T} 5(100 \%)$ & $\mathrm{CTM}$ \\
\hline Dry matter (DM) & 93.40 & 93.60 & 94.10 & 95.90 & 94.90 & 83.04 \\
Crude protein (CP) & 16.42 & 16.03 & 16.60 & 16.57 & 16.47 & 22.06 \\
Crude fibre (CF) & 8.00 & 12.00 & 13.00 & 14.00 & 13.00 & 10.07 \\
Ether extract (EE) & 3.00 & 4.00 & 4.00 & 3.00 & 4.00 & 5.37 \\
Total Ash & 2.00 & 2.00 & 4.00 & 1.00 & 4.00 & 5.60 \\
Nitrogen-free extract & 70.58 & 65.59 & 62.40 & 65.43 & 62.53 & 56.90 \\
(NFE) & & & & & & \\
ME(Kcal/kg) & 3356.13 & 3245.56 & 3153.40 & 3178.86 & 3152.82 & 3271.14 \\
\hline
\end{tabular}

$\mathrm{ME}=$ Metabolizable energy calculated according to the formula of (12):

$\mathrm{ME}=37 \mathrm{x} \% \mathrm{CP}+81 \times \% \mathrm{EE}+35.5 \% \mathrm{x} \mathrm{NFE}$

Table 3. Growth performance of rabbits fed different levels of cowpea testa meal

\begin{tabular}{lllllll}
\hline \multirow{2}{*}{ Parameters } & \multicolumn{3}{c}{ Levels of wheat offal replaced with cowpea testa meal } & \\
& T1 $(0 \%)$ & T2(25\%) & T3(50\%) & T4(75\%) & T5(100\%) & SEM \\
\hline Mean initial body weight (g) & 450.00 & 491.01 & 453.67 & 465.68 & 473.33 & $35.04^{\mathrm{NS}}$ \\
Mean final body weight (g) & $1127.0^{\mathrm{ab}}$ & $1283.36^{\mathrm{a}}$ & $1220.00^{\mathrm{ab}}$ & $1250.30^{\mathrm{ab}}$ & $1120.00^{\mathrm{b}}$ & $49.86^{*}$ \\
Mean daily feed intake(g/rabbit) & $58.95^{\mathrm{b}}$ & $67.99^{\mathrm{a}}$ & $55.33^{\mathrm{b}}$ & $54.76^{\mathrm{b}}$ & $56.96^{\mathrm{b}}$ & $2.23^{*}$ \\
Mean daily weight gain (g/rabbit) & 12.50 & 13.37 & 13.07 & 14.27 & 11.35 & $1.97^{\mathrm{NS}}$ \\
Feed conversion ratio (feed : gain) & 6.41 & 6.65 & 5.30 & 5.57 & 3.15 & $1.28^{\mathrm{NS}}$ \\
\hline
\end{tabular}

SEM = Standard error of mean; NS = Not significant $(\mathrm{P}>0.05) ; *=$ Significant $(\mathrm{P}<0.05)$;

$\mathrm{a}, \mathrm{b}=$ Means in the same row bearing different superscripts differ significantly $(\mathrm{P}<0.05)$

\section{Growth Performance}

The growth performance of the rabbits is shown in Table 3. The initial body weight, daily weight gain and feed conversion ratio were not significantly $(\mathrm{P}>0.05)$ different among the treatment groups while final body weight and daily feed intake were significantly $(\mathrm{P}<0.05)$ different among the treatments. Rabbits fed T2 (25\% cowpea testa meal) diet recorded the highest final body weight which is significantly $(\mathrm{P}>0.05)$ higher than those fed T5 (100\% cowpea testa meal) diet, but similar to the other treatments. The values obtained were higher than those reported by (22) who fed Asystasia gangetica leaf meal (ALM) as a replacement for wheat offal. The differences in final body weight recorded may be attributed to difference in the feed conversion ratio, composition of the diet and environmental condition during the experimental period. Rabbits fed T2 (25\% cowpea testa meal) consumed more feed than other treatments. The value recorded were similar to values reported by (22) who fed Asystasia gangetica leaf meal (ALM) as a replacement of wheat offal. The values (11.35 to $14.29 \mathrm{~g}$ ) obtained for daily weight gain in this experiment are within the range of 10 to $20 \mathrm{~g}$ reported for growing rabbit reared in the tropics (18). The values ( 3.15 to 6.65 ) for feed conversion ratio recorded in this experiment are similar to the values obtained by (16) that reared growing rabbits in same environment. 
IGWEBUIKE J. U., et al.

Table 4. Economic analysis of rabbits fed different levels cowpea testa meal

Levels of wheat offal replaced with cowpea testa meal

\begin{tabular}{llllllc}
\multicolumn{1}{c}{ Parameters } & $\mathrm{T} 1(0 \%)$ & $\mathrm{T} 2(25 \%)$ & $\mathrm{T} 3(50 \%)$ & $\mathrm{T} 4(75 \%)$ & $\mathrm{T} 5(100 \%)$ & SEM \\
\hline Initial weight (g/rabbit) & 450.00 & 491.01 & 453.67 & 465.68 & 473.33 & $35.04^{\mathrm{NS}}$ \\
Final live weight (g/rabbit) & $1126.70^{\mathrm{ab}}$ & $1283.30^{\mathrm{a}}$ & $1220.00^{\mathrm{ab}}$ & $1250.00^{\mathrm{ab}}$ & $1120.00^{\mathrm{b}}$ & $4^{*} .86^{*}$ \\
Total feed intake (g/rabbit) & 3301.20 & 3807.44 & 3099.60 & 3066.56 & 3190.88 & - \\
Total feed intake (kg/rabbit) & 3.30 & 3.81 & 3.10 & 3.07 & 3.19 & - \\
Total weight gain (g/rabbit) & 90.49 & 88.95 & 88.02 & 87.53 & 86.74 & - \\
Total weight gain (kg/rabbit) & 0.70 & 0.75 & 0.73 & 0.80 & 0.64 & - \\
* Cost/kg feed ( $)$ & 700.17 & 748.51 & 732.83 & 800.03 & 635.32 & - \\
Total feed cost ( $)$ & 283.11 & 324.84 & 262.69 & 258.56 & 267.00 & - \\
Cost/kg gain ( $/ \mathrm{kg})$ & 404.44 & 433.12 & 359.85 & 323.20 & 417.19 & -
\end{tabular}

* Cost per kilogram of the various ingredients used in compounding the experimental diets: Cowpea testa meal, N71.94; maize, $\mathrm{N} 74.07$; wheat offal, $\mathrm{N} 84.19$; groundnut cake, $\mathrm{N} 100.00$; groundnut haulms, $\mathrm{N} 80.00$; fish meal, $\mathrm{N} 125.00$; bone meal, $\mathrm{N} 50.00$; salt, $\mathrm{N} 10.00$ and premix, $\quad \mathrm{N} 1400.00$.

- = Not analyzed statistically

$\mathrm{SEM}=$ Standard error of mean

NS $=$ Not significant $(\mathrm{P}>0.05)$

$\mathrm{a}, \mathrm{b}=$ Means in the same row bearing different superscripts differ significantly $(\mathrm{P}<0.05)$

\section{Economic analysis}

The economic analysis of growing rabbits fed graded levels of cowpea testa meal is presented in Table 4. The total cost per $\mathrm{kg}$ feed decreased with increasing levels of cowpea testa meal in the diets due to the cheaper cost of cowpea testa meal ( 71.94) compared to wheat offal ( 84.19) which is the dietary component replaced by cowpea testa in the diets. The best feed cost/kg gain was observed in rabbits fed diet T4 (75\% cowpea testa meal) while the poorest $\operatorname{cost} / \mathrm{kg}$ gain was recorded in rabbits fed T2 (25\% cowpea testa meal). This may be attributed to the higher feed intake recorded by rabbits fed 25\% CTM. The lower cost per kg feed is an incentive that will warrant the replacement of wheat offal with cowpea testa meal in rabbit diet.

\section{CONCLUSION}

The results from this study revealed that up to $100 \%$ of wheat offal could be replaced with cowpea testa meal (CTM) in the diets of growing rabbits without adverse effect on the growth and economic performance of the rabbits. Additional advantage is reduced feed cost per kilogram as the level of cowpea testa meal increased in the diets. However, the best feed cost $/ \mathrm{kg}$ gain was obtained in rabbits fed T4 (75\% CTM).Therefore, farmers can use CTM as a replacement for wheat offal in rabbit diets without detrimental effect on performance.

\section{REFERENCES}

1. FAO African Agriculture, the next 25 years. Food and Agriculture Organization, U.N. Rome, Italy 1986
2. Ahamefule, F. O., Ejiofor,C. A. and Ibeawuchi, J. A., A comparative study of the constituents of cattle, sheep and goat milk in a hot humid environment. Discovery and Innovation. 15:64-68, 2000.

3. Njidda, A. A. and Isidahomen, C. E., Haematological parameters and carcasscharacteristics of weanling rabbits fed sesame seed meal (Sesamum indicum) in a semi- arid region. Pakistan Veterinary Journal. 31 (1): 35-39, 2011.

4. Bassey, I. O., Oluwatosin, O. O. and Olawoyin, O., Performance characteristics of rabbits fed millet bran as a replacement for wheat bran. African Journal of Animal Biomedical Science. 3 (2): 1-4, 2008.

5. Yusuf, A. M., Amusa, T. O. and Olafadehan, O. A., Performance of growing rabbits fed diets containing raw, roasted and re-roasted Afzelia Africana seed meal. Proceedings of the $36^{\text {th }}$ Annual Conference of Animal Science Association of Nigeria (ASAN), March $13-16^{\text {th }}$, Raw Material Research and Development Council, Abuja, Nigeria. Pp. 284-286, 2011.

6. Akinmutimi, A. H. and Ezea, J., Effect of graded levels of toasted lima bean (Phaseolus lunatus) meal on weaner rabbit diets. Pakistan Journal of Nutrition. 5(4): 368-372, 2006.

7. Alawa, J. P. and Umunna, N. N., Alternative feed formulation in developing countries: Prospects for utilization for Agro-industrial by-products. Journal of Animal Production Research.13 (2): 63-68, 1993.

8. Alabi, O. M., Adejumo, D. O. and Ladokin, A. O., Biochemical responses of cockerel to 
IGWEBUIKE J. U., et al.

graded levels of cowpea testa as replacement for groundnut cake. World Journal of Life Science and Medical Research. 1(6): 12-22, 2011.

9. AOAC., Official Methods of Analysis of Official Analytical Chemists. $17^{\text {th }}$ Edition. Horwitz, W., Washington, D.C., Association of Official Analytical Chemists. Pp.55-101, 2000.

10.Duncan, D. B., Multiple range and multiple F-tests. Biometrics 11: 1-42, 1955.

11.Steel, R. G. D. and Torrie. J. A., Principles and Procedures of Statistics. A Biometrical Approach, $2^{\text {nd }}$ Ed. Mc Graw. Hill Book Co. Inc. NewYork. Pp. 633, 1980.

12.Pauzenga, U., Feeding Parent stock. Zootecnica International: 22-25, 1985.

13.Odeyinka, S. M., Olosunde, A. S. and O.yedele, O. J., Utilization of soya bean milk residue, cowpea testa and corn starch residue by weaner rabbits. Livestock Research for Rural Development. Volume 3 Retrieved on 08/08/2014 at http:/www.cipav.org.co/Irrd/Irrd19/odey19 25.htm, 2007.

14.Olupona, J. A. and Balogun, O.O., Protein and energy values of some abbatoir byproducts for rabbits. Tropical Journal of Animal Science. 8(1): 33-37, 2005.

15.Lebas, F., Nutrient requirement and feeding meat rabbit. Journal of Applied Rabbit Research. 3:15-20, 1980.

16.Igwebuike, J. U., Anugwa, F. O., Raji, A. O., Ehiobu, N. G. and Ikurior, S. A., Nutrient digestibility, haematological and serum biochemical indices of rabbits fed graded levels of Acacia albida pods. ARPN Journal of Agricultural and Biological Science. 3(4): 33-40, 2008.
17.Igwebuike, J. U., Kwari, I. D., Diarra, S. S., Maggawa, D. D., Garba, A. P. and Musa, R., Replacement value of sprouted sorrel (Hibiscus sabdariffa) seed meal for groundnut cake in the diet of growing rabbits. Journal of Environmental Issues and Agriculture in Developing Countries. 2(1): 82-93, 2010.

18.Duwa, H., Girgiri, A. Y., Dauda, A. and Igwebuike, J. U., The effect of feeding graded levels of roasted sunflower (Helianthus annus L.) seed meal on weaner rabbits. Journal of Animal and Feed Research. 4(5): 107-112, 2014.

19.Aduku, A. O., and Olukosi, J. O., Rabbit Management in the tropics, Production, Processing, Utilization, Marketing, Economics, Practical Training, Research and Future Prospects. Living Books Series G. U. Publication, Abuja, Nigeria .Pp. 4356,1990

20.Cheeke, P. R., Rabbit Feeding and Nutrition. Academic Press Inc. Orlando, Florida, U. S. A . Pp 20-32, 1987.

21.Omole, A. J., Adejuyigbe, A., Ajayi, F. T and Fapohunda, J. B., Nutritive value of Stylosantes guianesis and Lablab purpureum as sole feed for growing rabbits. African Journal of Biotechnology 6(8): 2171-2173, 2007.

22.Adigun, O. S., Okeke, E. N., Makinde, O. J. and Umunna, M. O., Effect of replacing wheat offal with Asystasia gangetica leaf meal (ATM) on growth performance and haematological parameters of weaner rabbits. Greener Journal of Agricultural Science. 4(1):9-14, 2014. 